\title{
Research on Name and Function of the Chinese Guild Hall in Cholon Area Ho Chi Minh City
}

\author{
Yongzhi Wang \\ School of Tourism \& Culture, Yunnan Open University, Kunming, 650500, People's Republic of \\ China
}

wangyongzhi7404@163.com

Keywords: Cholon area, Chinese Guild Hall, Name, Function

\begin{abstract}
Cholon, Ho Chi Minh City, as main gathering place of Chinese in Vietnam, since the history recorded, in the course of hundreds of years exploring development history in Cholon, Ho Chi Minh City, with high historical and cultural value, abundant Chinese Guild halls are inherited, as precious wealth and witness of hundreds of years development history of Chinese people in Cholon. These guild halls are important carriers for the study of Chinese social and community production and life in Cholon area.
\end{abstract}

\section{Introduction}

In Ho Chi Minh City Vietnam, varieties of cultural colors were gathered and accommodated, including Chinese guild hall, which played an important role in the inheritance and stability of Chinese ethnic culture. Featuring distinctive unique cultural colors, reflecting exploring development history of Chinese people in Cholon area, Guild hall made outstanding contributions to economic and cultural development of Vietnam. Until now, guild hall in Cholon area had not only been an important cultural heritage of Vietnam Chinese, but also been accounted to vital function in the community life of local Chinese.

\section{Overview of Chinese Guild Hall in Cholon Area}

Nearly half of the 11 Chinese guild halls preserved in Cholon, Ho Chi Minh City had been built 300 years ago, mainly by immigrants from coastal provinces such as Guangdong, Fujian and Guangxi. The history of Chinese guild halls in Cholon was recorded by Zheng Huaide's Jiading City General Annals. "Guan Di Temple occupied at the north end of the street. Fuzhou, Guangdong, Chaozhou Guild halls stood at left and right sides. Tin Hau Temple located west in the middle of the street, slightly further west was Quan Am Pagoda. Zhangzhou Guild Hall sited at the south end of the street. " [1] At present 11 existing guild halls in Cholon covered Guangzhou Guild Hall, Nghia An Hoi Quan Pagoda, Quan Am Pagoda, Xia Zhang Guild Hall, Li Zhu Guild Hall, Qingfo Assembly Hall, San Shan Guild Hall, Er Fu Temple, Ming Xiang Jia Sheng Pavilion, Yi Run Pavilion, Qing Yun Nan Pavilion (Taoism pavilion)... The guild halls described in Jiading City General Annals were basically maintained; in modern times along with the development of Cholon, the quantity of Chinese guild halls had increased. Due to Chinese immigrants from China's coastal provinces had different origins and religious, and longtime reason, the names of these guild halls became complicated, examination and analysis works were needed to clear and identify. For ancient and modern time contrasting details, is shown in table 1. 
Table 1 Overview of Guild Hall in Cholon, Ho Chi Minh City

\begin{tabular}{|c|c|c|c|c|c|}
\hline $\begin{array}{l}\text { Guild Hall } \\
\text { Name }\end{array}$ & $\begin{array}{l}\text { Geographical } \\
\text { Dependency }\end{array}$ & $\begin{array}{l}\text { Construction } \\
\text { Time }\end{array}$ & $\begin{array}{l}\text { Site } \\
\text { Address }\end{array}$ & $\begin{array}{l}\text { Worshiped } \\
\text { God }\end{array}$ & $\begin{array}{l}\text { Ancient \& } \\
\text { Modern Contrast } \\
\text { (" Jiading City } \\
\text { General Annals ") }\end{array}$ \\
\hline $\begin{array}{l}\text { Guangzhou } \\
\text { Guild Hall } \\
\text { (Tin Hau } \\
\text { Temple, } \\
\text { Matsu } \\
\text { Temple, } \\
\text { Cholon Po } \\
\text { Temple) } \\
\end{array}$ & $\begin{array}{l}\text { Guangdong } \\
\text { Guild Hall }\end{array}$ & 1760 & $\begin{array}{l}\text { No. 710, } \\
\text { Nguyễn Trãi } \\
\text { Road,11th } \\
\text { Lane,5th } \\
\text { County, Ho Chi } \\
\text { Minh City }\end{array}$ & $\begin{array}{l}\mathrm{Ma} \mathrm{Zu} \\
\text { (Lin Monian) }\end{array}$ & $\begin{array}{l}\text { "Tin Hau Temple } \\
\text { located west in the } \\
\text { middle of the } \\
\text { street ". }\end{array}$ \\
\hline $\begin{array}{l}\text { Nghia An Hoi } \\
\text { Quan Pagoda } \\
\text { (Guan Di } \\
\text { Temple) }\end{array}$ & $\begin{array}{l}\text { Chaozhou } \\
\text { Guild Hall }\end{array}$ & 1684 & $\begin{array}{l}\text { No. } 678, \\
\text { Nguyễn Trãi } \\
\text { Road, 11th } \\
\text { Lane, 5th } \\
\text { County, Ho Chi } \\
\text { Minh City }\end{array}$ & Guan Di & $\begin{array}{l}\text { "Guan Di Temple } \\
\text { occupied at the } \\
\text { north end of the } \\
\text { street ". }\end{array}$ \\
\hline $\begin{array}{l}\text { Quan Am } \\
\text { Pagoda }\end{array}$ & $\begin{array}{l}\text { Fujian Guild } \\
\text { Hall }\end{array}$ & 1740 & $\begin{array}{l}\text { No.12, Laozi } \\
\text { Road, 11th } \\
\text { Lane, 5th } \\
\text { County, Ho Chi } \\
\text { Minh City } \\
\end{array}$ & $\begin{array}{l}\text { Ma Zu, } \\
\text { Guanyin } \\
\text { Bodhisattva }\end{array}$ & $\begin{array}{l}\text { "Slightly further } \\
\text { west was Quan } \\
\text { Am Pagoda ". }\end{array}$ \\
\hline $\begin{array}{l}\text { Xia Zhang } \\
\text { Guild Hall }\end{array}$ & $\begin{array}{l}\text { Zhangzhou } \\
\text { Guild Hall }\end{array}$ & $\begin{array}{l}\text { about early } \\
\text { 19th century }\end{array}$ & $\begin{array}{l}\text { No. 802, } \\
\text { Nguyễn Trãi } \\
\text { Road, 14th } \\
\text { Lane, 5th } \\
\text { County, Ho Chi } \\
\text { Minh City } \\
\end{array}$ & $\begin{array}{l}\text { Ma Zu, God } \\
\text { Fude, Guanyin } \\
\text { Bodhisattva, } \\
\text { etc. }\end{array}$ & $\begin{array}{l}\text { "Zhangzhou Guild } \\
\text { Hall sited at the } \\
\text { south end of the } \\
\text { street." }\end{array}$ \\
\hline $\begin{array}{l}\text { Li Zhu Guild } \\
\text { Hall (Li Zhu } \\
\text { Temple) }\end{array}$ & $\begin{array}{l}\text { Silversmith } \\
\text { Industry } \\
\text { Guild Hall }\end{array}$ & 1893 & $\begin{array}{l}\text { No. 586, Chen } \\
\text { Xingdao Road } \\
\text { B, 14th Lane, } \\
\text { 5th County, Ho } \\
\text { Chi Minh City }\end{array}$ & $\begin{array}{l}\text { Silversmith } \\
\text { Industry } \\
\text { Founder }\end{array}$ & - \\
\hline $\begin{array}{l}\text { Qingfo } \\
\text { Assembly } \\
\text { Hall } \\
\text { (Hainan } \\
\text { Sheng Mu } \\
\text { Temple ) }\end{array}$ & $\begin{array}{l}\text { Hainan Guild } \\
\text { Hall }\end{array}$ & 1824 & $\begin{array}{l}\text { No. 176, Chen } \\
\text { Xingdao Road } \\
\text { B, 14th Lane, } \\
\text { 5th County, Ho } \\
\text { Chi Minh City }\end{array}$ & $\begin{array}{l}\text { Ma Zu, } \\
\text { Emperor } \\
\text { Wenchang, etc. }\end{array}$ & - - \\
\hline $\begin{array}{l}\text { San Shan } \\
\text { Guild Hall } \\
\text { (San Shan } \\
\text { Temple, San } \\
\text { Hui Temple) }\end{array}$ & $\begin{array}{l}\text { Fuzhou Guild } \\
\text { Hall }\end{array}$ & $\begin{array}{l}\text { Mid-18th } \\
\text { century }\end{array}$ & $\begin{array}{l}\text { 118th, Zhao } \\
\text { Guangfu Street }\end{array}$ & $\begin{array}{l}\text { Ma Zu, Guan } \\
\text { Gong, etc. }\end{array}$ & $\begin{array}{l}\text { "Fuzhou, } \\
\text { Guangdong, } \\
\text { Chaozhou guild } \\
\text { halls stood at left } \\
\text { and right sides." }\end{array}$ \\
\hline Er Fu Temple & $\begin{array}{l}\text { Chaozhou } \\
\text { Guild Hall }\end{array}$ & 1765 & $\begin{array}{l}\text { No. 264, } \\
\text { Laiweng Road, } \\
\text { 14th Lane, 5th } \\
\text { County, Ho Chi } \\
\text { Minh City }\end{array}$ & God Fude & $\begin{array}{l}\text { "Fuzhou, } \\
\text { Guangdong, } \\
\text { Chaozhou Guild } \\
\text { halls stood at left } \\
\text { and right sides." }\end{array}$ \\
\hline
\end{tabular}




\begin{tabular}{|c|c|c|c|c|c|}
\hline $\begin{array}{l}\text { Ming Xiang } \\
\text { Jia Sheng } \\
\text { Pavilion }\end{array}$ & $\begin{array}{l}\text { Ming Heung } \\
\text { Guild Hall }\end{array}$ & 1778 & $\begin{array}{l}\text { No.380, Chen } \\
\text { Xingdao Road, } \\
\text { 11th Lane, 5th } \\
\text { County, Ho Chi } \\
\text { Minh City }\end{array}$ & $\begin{array}{l}\text { Cheng Huang } \\
\text { Gods, Kitchen } \\
\text { God and other } \\
\text { statues such as } \\
\text { Zheng Huaide, } \\
\text { Wu Renjing }\end{array}$ & —— \\
\hline $\begin{array}{l}\text { Yi Run } \\
\text { Pavilion }\end{array}$ & $\begin{array}{l}\text { Ming Heung } \\
\text { Guild Hall }\end{array}$ & $\begin{array}{l}\text { About early } \\
\text { 19th century }\end{array}$ & $\begin{array}{l}\text { No. 17th, Pan } \\
\text { Wenzhuang } \\
\text { Road, 13th } \\
\text { Lane, 5th } \\
\text { County, Ho Chi } \\
\text { Minh City }\end{array}$ & $\begin{array}{l}\text { Guan Di, Guan } \\
\text { Ping, Zhou } \\
\text { Cang, etc. }\end{array}$ & —— \\
\hline $\begin{array}{l}\text { Qing Yun } \\
\text { Nan Pavilion }\end{array}$ & Taoist Pavilion & 1934 & $\begin{array}{l}\text { No. 169th, Pan } \\
\text { Ruan Shi } \\
\text { Road, 16th } \\
\text { Lane, 11th } \\
\text { County, Ho Chi } \\
\text { Minh City }\end{array}$ & $\begin{array}{l}\text { Buddha, } \\
\text { Confucius, } \\
\text { Laozi and etc. }\end{array}$ & - \\
\hline
\end{tabular}

(Note: On the basis of study by Chen Jinghe scholar and Basso British famous expert of oversea Chinese history, Li Qingxin considered that "Ming Xiang People" meant oversea Chinese, politically immigrated into Vietnam in large number after the 1640s Ming Dynasty, "Maintaining Ming Dynasty Incense", formed a special group Vietnamese alien, known as "Ming Xiang" (Minh-Huong), their village community known as the Ming Xiang Community, that was a primary-level organization with autonomous feature in Vietnam. In July Eight Year of Sheng Zu Ming Ming (1827), the name changed as Ming Heung Community. Ming Heung People included both Chinese people who entered Vietnam during revolution period in the Ming and Qing dynasties, as well as early Vietnamese native Chinese and the children of Chinese and native Vietnamese by marriages. ) [2]

\section{Characteristics of Chinese Guild Hall}

In the field survey of Chinese guild hall in Cholon, Ho Chi Minh City, the author found that the Chinese society and religious system united as one, "Guild Hall" and "Temple" directly showed this characteristic with blurring boundary, mutual use of the name and convergence of their functions.

In Chinese social life, worship place was usually called Si Miao (Temple). In fact, there is different between "Si" and "Miao", the place to worship Buddha was called as "Si", God as "Miao", and Taoist pavilion as "pavilion" or "palace." However, the places of worshiping God or Buddha did not strictly distinguish at Chinese community in Cholon area, even the only Taoist pavilion was also called as temple. According to the early history record, the religious places guild hall and temple were distinguish separately, were two independent activities places; only their locations were near. Then why the Chinese guild hall in Cholon area was called "Temple"? In the course of historical development, due to the turmoil of war, social change, business activity and other reasons, the Chinese guild hall had been damaged many times, then many times reconstruction and restoration, the Chinese guild hall was often reset up at folk religious place, after a long time, the Chinese guild hall gradually became part of the religious system, merged into one system eventually. Guild hall was called "Temple", and in turn, the temple was called "Guild Hall". This phenomenon was rarely seen in mainland China. Therefore, the Chinese guild hall in Cholon area had a variety of appellation, such as "Temple", "Pavilion", "Guild Hall", "Courtyard" and so on, and owned comprehensive functions of religious belief, trade management and public welfare, which became the core of Chinese community life. 


\section{Category of Chinese Guild Hall in Cholon Area}

Guild Hall, " People from the same city, the same prefecture or the same county, migrated and gathered in groups, built the premises, and met together to strengthen their friendship and fellowship connections." [3]It gave alms and pension to the one in poverty or unemployment. Sometimes it set up public grave for funeral affairs. Merchant business was set up, too. The Chinese nation attached importance to consanguinity, kinship and geopolitics in traditional cultural concept. Like domestic guild hall, it often played an important link and tie role in the overseas business activities and immigration society. According to its function, the Chinese guild hall in Cholon area was divided into three types, namely, geo-type, industry-type and religion-type.

\subsection{Geo-type Guild Hall}

In oversea Chinese society, immigrants from the same region or the same dialect area often formed a geo-type guild hall, among Chinese guild hall in Cholon area, Nghia An Hoi Quan Pagoda, Quan Am Pagoda, Xia Zhang Guild Hall, Qingfo Assembly Hall, Ming Xiang Jia Sheng Pavilion, Yi Run Pavilion, Er Fu Temple, all belonged to geo-type guild hall. See the table below.

Table 2 Overview of Geo-type Guild Hall in Cholon

\begin{tabular}{l|l|l}
\hline Guild Hall Name & $\begin{array}{l}\text { Geographical } \\
\text { Dependency }\end{array}$ & \multicolumn{1}{c}{ Builders } \\
\hline Qghia An Hoi Quan Pagoda & Chaozhou Guild Hall & Chaozhou immigrants \\
\hline Xia Zhang Guild Hall & Fujian Guild Hall & $\begin{array}{l}\text { Quanzhou Prefecture } \\
\text { Immigrants }\end{array}$ \\
\hline Qingfo Assembly Hall & Hainan Guild Hall & $\begin{array}{l}\text { Zhangzhou Prefecture } \\
\text { Immigrants }\end{array}$ \\
\hline $\begin{array}{l}\text { Ming Xiang Jia Sheng } \\
\text { Pavilion }\end{array}$ & $\begin{array}{l}\text { Ming Heung Guild } \\
\text { Hall }\end{array}$ & Ming Heung People \\
\hline Yi Run Pavilion & $\begin{array}{l}\text { Ming Heung Guild } \\
\text { Hall }\end{array}$ & Ming Heung People \\
\hline Er Fu Temple & Chaozhou Guild Hall & $\begin{array}{l}\text { Zhangzhou and Quanzhou } \\
\text { Prefecture immigrants }\end{array}$ \\
\hline
\end{tabular}

This type of guild hall, according to the immigrant group nature, also could be subdivided to two kinds of situations. One kind was Ming Heung guild hall, the other was ordinary merchant guild hall. Organization and function differed between these two kinds of guild halls. According to the foregoing, Ming Heung People were the political immigrants to Vietnam in the Ming and Qing dynasties, aiming "Maintaining the Ming Dynasty Incense"; merchant guild hall was mainly built by merchant or war refugee from China's coastal city and same dialect area, who settled together and made a living in Cholon area.

\subsection{Industry-Type Guild Hall}

Industry-type guild hall was mainly composed of merchants from the same industry, such as Li Zhu Guild Hall. On-the-spot investigation, according to the introduction of management staff, the founder of a Chen surname Chinese silversmith in Saigon was enshrined here at Li Zhu Guild Hall. 
The hall also enshrined canonization copy of silversmith founders Gao Tingdu and Gao Tingxiang, which was granted by Vietnam Emperor Kai Ding and Emperor Bao Dai. Learned from four pieces of inscriptions contents presented in the hall, Li Zhu Guild Hall was donated and founded by the Chinese and Vietnamese silversmith in the areas of Saigon, Cholon, Tra Vinh, Binzhi, and Can Tho, etc. Vietnamese scholar Wang Hongsheng wrote: "Starting from Nguyễn Trãi Road, passing through the governor Fang's Government Prefecture, Li Zhu temple was at the sight. It was ancestral temple offering to the silversmith and the jewelry shop owner. Thereafter with participation of oversea Chinese silversmith, the annual sacrifice ceremony held very solemn and dignified. " [4] Li Zhu Guild Hall was a typical industry guild hall, which not only reflected the development of the Chinese goldsmith industry in Cholon area, but also witnessed the integration of Chinese gold and silver handicrafts with the local handicrafts in Vietnam."

\subsection{Religious Guild Hall}

In Vietnam Chinese communities, worship place was often called temple; guild hall, even Taoist pavilion were called temples, too. The guild hall was usually set up in the folk religious place of Chinese community, in the long-term Vietnam localization process of immigrants, the Chinese ethnic groups and faiths gradually merged, the guild hall was usually called "Temple", on the contrary, the temple was also called "Guild Hall", without distinction. This phenomenon was rare among China's domestic guild halls and temples. The Qing Yun Nan Pavilion belonged to this type. The Qing Yun Nan Pavilion Taoist was built in 1934, while Foshan Qing Yun Dong Taoist monks spread Taoism to Chinese in Cholon area, during the local community integration process, Qing Yun Nan Pavilion a single religious place evolved into guild hall with functions of worship, trade, communication and etc.

\section{Function of Chinese Guild Hall in Cholon Area}

Professor Chen Honglian, Vietnamese scholar, pointed out that the ancestral hall and guild hall would be established wherever Chinese settled down. [5] The guild hall played an important role and function in Chinese society.

\subsection{Sacrificial Rites Function}

"The Rite had five classics, the sacrifice got priority", Chinese nation had always attached importance to worship ancestor and god, by worshipping activities to respected and appreciated ancestors' virtues, sought blessing for folk descendants, at the same time by the invisible force to enhance social order management, and strengthen cohesion. Chinese guild hall in Cholon area provided place to worship sages and ancestors. In 1778 Ming Xiang Jia Sheng Pavilion (Ming Heung Guild Hall) was built by Ming Heung people to worship Chen Shangchuan, Wu Renjing, Zheng Huaide, Mao Jiu and other sages' statues, while pursuing and admiring ancestors' pioneering efforts. Although different gods was worshiped, 11 guild halls in Cholon area held ceremonious seasonal festival sacrificial activities; incenses were exuberant.

\subsection{Business Management Service Function}

One important function of Chinese guild hall was to seek business development, mutual help, common regulations, market standardization, relying on group strength of same region, same dialect or same industry. During the Ming and Qing dynasties, the sea trade activities were very difficult, with not only adverse effects of the harsh natural environment, but also the social unrest, war and cunning market behavior to overcome. The risk of business activities was large, if there were no group power and mutual help, it was difficult to carry out business smoothly. Reconstruction of the Guangzhou Guild Hall Inscription (1830) recorded: "It was said that the construction of the guild hall was to reward the grace and help, contact with friendship and fellowship also. From north to south, the sailing was smooth and instantaneous. Developing business, making prosperous business, enjoying mutual help, Yi Yu colleagues called for the public thrift spirit. [6]It was visible, guild hall as a resting place and shelter, where traveling businessmen not only prayed for blessing of $\mathrm{Ma} \mathrm{Zu}$, 
but also enhanced communications. With the development of the society, the commercial function of the Chinese guild hall in the current Cholon area had been gradually diluted, but it was still a place to worship God and foster fellowship for oversea Chinese merchants

\subsection{Social Governance Function}

During the developing history of Ho Chi Minh City, Vietnam, Cholon area was the newly developed area, where large-scale Chinese population gathered and lived in the mid-late 17th century. Zheng Huaide's "Jiading City General Annals" recorded "Xian Zun Xiao Ming Emperor, Wu Yin eight years (1698), commanded Zhang Qi Li Cheng Hou Ruan (You Jing) to govern Gao Man. Jiading Prefecture was set up... thousands of miles land, more than 40,000 households, immigrants within the region recruited. To set up the villages, divide the land, cultivate farming soil, regulate rental rules, and compile Dingtian records. So Chinese and their descendants lived at Zhen Bian was named as Qing He community, the Pan Zhen area as Ming Xiang community, with household compiled. [7]Chen Jinghe pointed out: "There were a lot of indications that the newly developed $\mathrm{Lu}$ Ye area, Cholon attracted many Chinese businessmen from Hui An Ming Xiang community and Shun Hua $\mathrm{He} \mathrm{Bu}$ area to engage in business or pioneering, until Ruan Fu dynasty set up Jiading Prefecture, then name the village of the new community with place name of their origin. [8]Ruan dynasty carried out the policy of "compiling households" to the Chinese who newly-moved to Cholon area, set up primary social organizations such as "Ming Xiang Community", and adopted "board and simple legislation ", "generous law and less tax ". [9] Jiading City officials claimed: "Tang people (Chinese) made life in the city, opened private shop; the city classified and set up leading positions to rule and govern the place, among people from Fujian, Guangdong, Chaozhou, Hainan and other place,." [10] This was the origin of Chinese immigrant autonomy organization. "Ming Heung Community" set up many ruling positions, such as Gai She, Xiang Lao (Xiang Shen, Xiang Mu ), Xiang Zhang, Xun Dao (Xiang Gong, Li San Shi Wu), Zhen Zhang (Lin Zhang), Fu Zhang, Jia Shou (representatives) and other staff. [11] Ruan dynasty granted the Chinese community a fairly autonomous power, such as Ming Heung Community. Zheng Huaide's "Jiading City General Annals" recorded: "At community sacrifice ceremony time, each township built own guild hall, the sacrificial time chose in advance, elder and younger ones stayed together overnight, and this was called Su Ye. In the following morning, every one dressed up, ceremony started... Xiang officials, knowledgeable ones, got the priority during the ceremony activities, drinking rituals, speaking of the law, setting up township treaty. During the ceremony, tax payment, taking the corvee, a year profit, close an account, all calculated clearly ... with regulations obeyed. " [12] It could be seen that, at the time major sacrificial activities carried out in Chinese guild hall in Cholon area, important social governance activities also carried out, such as sacrificial rites, " law illustration ", "treaty explanation", taxes levying, taking the corvee, public accounts clearing, etc.. It reflected that Chinese guild hall was an important forum for the Chinese community, with the daily economic activities, public property management, clear legal treaty, formulate etiquette regulation, rectify the customs, primary social governance were carried out to communicate and unite the public and maintain the Chinese social order and stability.

\subsection{Cultural Heritage Function}

The Guild Hall was an important cultural heritage site, related historical materials mentioned in Zheng Huaide's "Jiading City General Annals". About the basic cultural characteristics of "Ming Heung People ", the Dictionary of Overseas Chinese mentioned that although the Ming Heung People had taken the Vietnamese nationality, but still maintained the Chinese traditional culture heritage, constructing temple, enshrined incense lamp, continuing the Ming Dynasty dressing customs, speaking Chinese language, learning the Cantonese, and remaining inheritance relationships. "[13] The guild hall itself was a kind of concrete manifestation of culture, and also one of the important heritage carriers of culture." "At community sacrifice ceremony time, each township built own guild hall... dressing up, following ritual. In the next day, sacrifice activities ended, all accomplished, all retreated. For sacrifice time choosing according own different customs, 
spring for Chun pray, autumn for Qiubao pray, or winter for Year-end pray. Worshipping own gods to pray for good blessing. Like the offerings, the singing process followed own customs. Xiang officials, knowledgeable ones, got the priority during the ceremony activities, drinking rituals, speaking of the law, setting up township treaty. [14] This historical record contained abundant information, the time, form, content, etiquette and law of the sacrificial rites were all Chinese culture of in Cholon area, and the culture heritage had been passed so far so far.

Today in Cholon area, during Mazu's birthday, Sanyuan Festival and other major festivals, the Guangzhou Guild Hall held entertainment performance several days in the evening; Nghia An Hoi Quan Pagoda held a solemn ceremony every year on June 24th, worshiping Guan Gong; Li Zhu Guild Hall, the annual Lunar February 7th commemorative activities held to worship gold and silver jewelry ancestor, held three consecutive days of sacrificial activities, the scene was very lively grand, reading eulogy oration, organizing Temple Park activities, Dragon dances, lion dances, opera, Cantonese opera, etc... These solemn activities and ceremonies were praying for blessings and also helping young people to recognize and value good cultural traditions of their own groups.

Now in Guangzhou Guild Hall placed the Journey to the West, the Eight Immortals Crossing the Sea, Reincarnation, Three Visits to the Cottage, the Chinese Ghostbuster and other Chinese allusions pottery, there were the twenty four Filial Exemplars, Sihao, Zhou Chu Elimination Three Evils and other 34 of murals, hanging on the wall Li Bai's " Trip to Jiangling ", Wang Bo's " Preface to Tengwang Pavilion" and Other Poems calligraphy banners and works; On the pillars of the temple, Carved 23 pairs of Chinese characters couplets ... These guild halls and temples followed China's southeastern coastal provinces in the building shape, structure, layout, style of Thean Hou Temple and other ancient buildings in the same lineage. Inside Guild Hall set up a statue of God, couplets murals, items placed, landscape sketches, all reflected the function of Chinese culture heritage and punishing and enlightening.

\subsection{Public Entertainment Activities Venue}

The guild hall was the place to foster fellowship between oversea Chinese from the same native place, was the venue for Chinese community public activity, and also the entertainment site. Guild Halls in Cholon area all owned this basic function. "Cholon was apart $6 \mathrm{~km}$ from the south of the town ... Guan Di Temple occupied at the north end of the street. Fuzhou, Guangdong, Chaozhou Guild halls stood at left and right sides. Tin Hau Temple located west in the middle of the street, slightly further west was Quan Am Pagoda. Zhangzhou Guild Hall sited at the south end of the street." In beautiful morning and evening, magnificent times, hanging lights, placing desks, fighting the odd, feeling like Fire Tree Star Bridge, prosperous scene, pleasures laughing around, men and women surrounded, joys hanging over the bustling street. "[15] also " solemn temple, lonesome Chan Guan, poets and visitors, annual Qingming and Chongjiu leisure times, several friends going along, sitting together and appreciating flowers, enjoying and expressing spontaneously, overlooking the noisy dust, widening the horizon. "[16] It could be seen that the Chinese guild hall carried out public and recreational activities by seasonal festivals, sacrificial ceremonies and gatherings, and as a symbol of spiritual culture, the guild hall buildings were stately and magnificent, with a strong sense of art and an important sight for people to rest and visit.

\subsection{Social Welfare Activities}

Since the Tang and Song dynasties, Chinese commercial people from coastal cities, Guangdong, Fujian and others, went overseas to make a living or avoid the conflicting, with the expansion of An Nan, large-scale immigration to Nan Qi. At that time Nan Qi was the newly developed area, unfamiliar environment, bad natural condition, endless war between An Nan and Gao Man (Cambodia), hard survival condition. Chinese immigrants could only communicate their nostalgia, look after each other, seek common livelihoods, and live together to meet the challenges and disadvantages of nature and society. With the production activities of wasteland farming, shop opening, trade and transportation, ancestral halls, temples were built; chambers of commerce, guild hall, school were set up; the center of Chinese life gradually formed. Reconstruction of the 
Guangzhou Guild Hall Inscription (1830) recorded: "It was said that the construction of the guild hall was to reward the grace and help, contact friendship and fellowship also. From north to south, the sailing was smooth and instantaneous. Developing business, making prosperous business, enjoying mutual help, Yi Yu colleagues called for the public thrift spirit. [17] This historical material mentioned, with friendship and fellowship as belt and link, Chinese merchants making prosperous business, helping each other. It reflected the common welfare function of guild hall. Related record about guild hall in Cholon area was rare, but we could make a circumstantial evidence from the inscription at Zhong Hua Guild Hall of Hui An. In 1741, a stone tablet was erected at Zhong Hua Guild Hall of Hui An to establish the Foreign Chamber of Commerce Ordinance. "The guild hall was set up for a long time. It was the place of proceedings and counseling, basically place of etiquette and righteousness. To follow fair and justice, settle disputes, and there was not the same case. Worshiping $\mathrm{Ma} \mathrm{Zu}$ at festivals and ceremonies year after year, along with concentric forces, Chinese oversea gathered to develop business, confront injustice, seek good blessing, and help each other in disease and adversity, and so on... A discussion, if a person in difficulties was allowed to live in the guild hall for three months, paying 300 injection of money each month as accommodation fee. The one encountered stranding of cargo ship, needing help, could temporarily rest until the ship set sail, accommodation fee free, staying for a short time only. Another discussion, if the one encountered stranding of cargo ship, getting sick, paying 300 injection of money each month as accommodation fee, leaving the guild hall once healed, long time staying was not allowed. Monks and Xiang Gong should learn the patient's place of origin, name, and boat detail, in case fraud. If the one died unfortunately, giving 2 injection of money for funeral ... "[18] From the above cited inscription, the Zhong Hua Guild Hall in Huian offered helps to Chinese in distress and sick, specifying measures and standards of different situations accordingly. The Zhong Hua Guild Hall in Huian was constructed by joint venture of Fujian, Guangdong, Hainan, Chaozhou and Hakka, as common guild hall of local Chinese, as an important representative of Chinese guild halls, which had more or less similar functions. Even if the current social situation changed, the public welfare function of the guild hall still existed. For example, Guangzhou Guild Hall in Cholon district established Guangzhou-Yuexiu School in 1910, later in1958 founded Fuxing school to enroll Chinese children, in 1967 presented the Guangzhao Hospital with a fertility home, and etc. [19] Throughout the ages, the Chinese guild hall in Cholon district had been carrying out public welfare activities, helping to save the one in hardship and playing a charitable public function.

\section{Conclusion}

Guild Hall originated from Chinese regional local culture, promoted the outward development of local culture in return, and combined material and spirit of Chinese society. The Chinese Guild Hall, as the core spiritual symbol and the local friendship belt in the Chinese Immigrant society in Cholon area, played a special role in the historical development of Cholon area. These guild halls, through their own inclusive functions, continuously facilitated the development of Chinese society in Cholon area. Even if the economy, technology and cultural level were highly developed, these halls still played its ancient role and function, sheltering the stability and peace of the overseas Chinese society, including Cholon area.

\section{References}

[1] Dai Kolai and Yang Paoyun checked and annotated. Three kinds of historical materials, such as The Lingnan Mystery Stories [M], Henan: Zhongzhou Ancient Books Publishing House, 1991:213

[2] Li Qingwin. Vietnamese Ming xiang and Ming Heung Society [J], China Social History Review, 2009 (10): 205-223 
[3] Fang Yi, Chen Jong, etc. Etymology [M], Shanghai: Commercial Press, 1933

[4] Vuong Hong Sen. Year Saigon [M], Ho Chi Minh City: Ho Chi Minh City Publishing House, 1991:195

[5] Tran HongLien. The integration, the Vietnamese beliefs and religions of the Chinese ones from 17th century to now [J], "Pan-Pearl River Delta and the South China Sea Trade" International Symposium on Academic Papers, Zhaoqing, Guangdong, 2004: 117-185

[6] Li Wenjing. Guangzhou Guild Hall Tin Hau Temple [M]. Ho Chi Minh City: Ho Chi Minh City Publishing House, 2000:46

[7] Dai Kolai and Yang Paoyun checked and annotated. Three kinds of historical materials, such as The Lingnan Mystery Stories [M], Henan: Zhongzhou Ancient Books Publishing House, 1991:123

[8] Chen Jinghe. The Transplant to NamKỳ of Zheng Chenggong Remnants in early Qing Dynasty (next) [J], New Asia Journal, 1968 (8): 451-452

[9] Dai Kolai and Yang Paoyun checked and annotated. Three kinds of historical materials, such as The Lingnan Mystery Stories [M], Henan: Zhongzhou Ancient Books Publishing House, 1991:126

[10]The Book of Great South Chronicle (second) volume 40, Minh Mạng July, 7year (1826)

[11]Chen Jinghe. Cheng Tian Ming Heung Society Chen's Pedigree [M], Institute of the Chinese University of Hong Kong, 1964 (8): 5-6; quoted from Li Qingxin. Trade, transplant and cultural exchange: 15-17 century Guangdong people and Viet Nam [J]. China Social History Review, 2009 (6): 146-151

[12]Dai Kolai and Yang Paoyun checked and annotated. Three kinds of historical materials, such as The Lingnan Mystery Stories [M], Henan: Zhongzhou Ancient Books Publishing House, 1991:177

[13]Editorial Board of Overseas Chinese Dictionary. Overseas Chinese Dictionary [M], Taipei: Overseas Chinese Association General Association: 1990:401

[14]Daikolai, Yang Paoyun Chong. Three kinds of historical materials, such as The Lingnan Chronicles [M], Henan: Zhongzhou Ancient Books publishing house, 1991:177

[15]Dai Kolai and Yang Paoyun checked and annotated. Three kinds of historical materials, such as The Lingnan Mystery Stories [M], Henan: Zhongzhou Ancient Books Publishing House, 1991:213

[16]Dai Kolai and Yang Paoyun checked and annotated. Three kinds of historical materials, such as The Lingnan Mystery Stories [M], Henan: Zhongzhou Ancient Books Publishing House, 1991:208

[17]Li Wenjing. Guangzhou Guild Hall Tin Hau Temple [M]. Ho Chi Minh City: Ho Chi Minh City Publishing House, 2000:46

[18]Chen Ching- Ho.On the Rules and Regulations of the "Duong- thuong Hoi- quan"of Faifo (Hoi- an), Central Vietnam [J]. Southeast Asian Archives, 1969 (2) 87-96

[19]Li Wenjing. Guangzhou Guild Hall Tin Hau Temple [M]. Ho Chi Minh City: Ho Chi Minh City Publishing House, 2000:46 